\title{
South, South East and East Asia: Economic Miracle but
}

\section{Environmental Disaster}

\author{
Jan-Erik Lane ${ }^{1 *}$ \\ ${ }^{1}$ Fellow at the Public Policy Institute, Belgrade \\ *Jan-Erik Lane, E-mail: janeklane@gmail.com \\ Address: 10 Charles Humbert, 1205 Geneva; 559 A, 3rd Floor, Thuya Street, 9 th Quarter, Yangon. \\ Myanmar.
}

Received: October 26, 2016 Accepted: November 15, 2016 Online Published: November 16, 2016

doi:10.22158/se.v2n1p1 URL: http://dx.doi.org/10.22158/se.v2n1p1

\begin{abstract}
United Nations Framework Convention on Climate Change-unfccc-appears to run into difficulties at the same time as it is holding its COP22 meeting in Morocco. The COP21 Agreement in Paris 2015 was merely a promise and no implementation has taken place. Now, the US under a new president could engage in the classical collective choice strategy of reneging. Coordination failures would make global warming all but certain, which constitutes an enormous NEGATIVE for the Asian miracle economies. If temperature rises $>4$ degrees in the equator areas of Asia, then work, affluence, health, food as well as land and sea will be very badly affected.
\end{abstract}

\section{Keywords}

energy-emissions conundrum, country GHG predicaments, Asian economic miracle, Kaya model, UNFCCC, carbon emissions.

\section{Introduction}

It is true that climate change and its implications are given much more attention now, after the COP21 Agreement in Paris. There are almost weekly conferences about global warming and the debate is intense all over the globe. This is a positive, but one must point out the exclusive focus upon natural science and technological issues, which actually by passes the thorny problems of international governance and the coordination of states. The social science aspects of global warming policy-making will be pointed out in this article. This is a problematic by itself that reduces the likelihood of successful implementation of the goals of the COP21 Agreement (Goal I, Goal II and Goal III in global decarbonistion). 


\section{Uncertainties}

It is quite understandable that the focus in all the international conferences, some of which are now speaking of COP22 meetings, is upon the natural science issues in climate change. They deal with how dangerous the global warming process could be as well as the feasibility of halting this trend in the 21 th century by various measures, like for instance carbon capture. Yet, by neglecting some very relevant social science models, the COP21 approach of decarburization will run into major difficulties, already in the next decade. Can really international governance together with states coordination deliver policies and will they be implemented in a decentralized approach? The question is most relevant, even when the natural sciences and technology arrives at conclusive answers to the major issues in climate change.

It seems to me that the key issues in the global climate change debate concerns inter alia the following:

1) What more precisely is the link between the amount of carbon in the atmosphere and the rise of temperature, in sea and $\mathrm{n}$ land? Is it a linear or non-linear link? Thresholds? Reversibility?

2) How and when will rising temperatures in sea and at land affect basic environmental aspects, like the ice layers and the frozen waters as well as glaciers?

3) How much carbon will be stocked in the atmosphere in this century, given alternative scenarios of emissions and natural carbon uptake? How dangerous could increasing GHG:s like methane be?

4) Is it at all feasible to accomplish massive decarbonisation of the air by means of carbon sequestration at what costs?

Having full knowledge about all these issues would improve much upon the theories of global warming and would be extremely useful in practice when policies are to me made about decarbonisation.

Yet, they do not comprise the implications of lessons of the social sciences for global governance, coordination and policy making. The crux of the matter is what I call the Wildavsky hiatus: policies however appealing are bound to fail when put in practice, as no policy is self-implementable (Pressman \& Wildavsky, 1973, 1984). To grasp the feasibility of the COP21 project and its three goals of decarbonisation, one must understand the implementation deficit and the coordination failures. I will spell out these concepts here in relation to the COP21 framework, and its three objectives, namely:

a) Halting the increase in carbon emission up to 2020 (Goal I);

b) Reducing CO2:s up until 2030 with 40 per cent (Goal II);

c) Achieve more less total decarbonisation until 2075 (Goal III).

It is up to the governments of the countries to implement these goals with rather weak overview from international governance but with the promise of assistance from a huge Super Fund. What, then, are the INCENTIVES involved in decentralised decarbonisation a la COP21? To discuss decarbonisation feasibility along the three goals - Goal I, Goal II and Goal III-one need to take into account the restrictions on human action and interaction in social systems, spelled out in economic theory and game theory. 


\section{Reneging: Coordination Failures}

Just because there is an agreement it does not entail it will be respected. Even if respecting the promises made is the best strategy for all partners to the dal, each individual has an incentive to renege upon the agreement. In two-person game theory, a few much discussed models portray coordination failures, and they are applicable to governments as well as international governance. If, as shown above with the Kaya model, decarbonisatin may be costly, hurting economic development, then perhaps a country may simply go its own way, leaving it up to the other(s) to handle the externalities in global warming. Why make costly contributions to collective action? Remember that small countries do not matter much (N-1 problematic) and huge countries would have to share the benefits with all others (I/N problematic).

The interaction between nations and their governments can be of two kinds: zero sum game or variable sum game. Halting the climate change process constitutes a Pareto optimal goal for all participants with means of collective action, coordination either by themselves or with a third party, an international governance body like that of the UNFCCC. However, coordination may fail to reach a set of Pareto optimal outcomes, as the choice participants chose Pareto inferior strategies due to self-interest seeking with guile. Coordination failures arise when individual rationality prevails over collective rationality:

-Reneging (PD game);

-Threat (Chicken game);

-Sub-optimality (Negotiation game);

-Second best solutions (Assurance game).

A few examples of these possible coordination failures in the management of the global warming process are stated below, where also financial help from a Super Fund enters the gaming strategies. Thus for instance, poor countries with huge total emissions may demand much larger reductions percentage wise from rich countries with high per capita emissions. Unless accepted, they renege upon the COP21 objectives of decarbonisation.

\section{Energy-Emission Conundrum}

The basic theoretical effort to model the greenhouse gases, especially $\mathrm{CO} 2 \mathrm{~s}$, in terms of a so-calledidentity is the deterministic Kaya equation. The Kaya identity is of the "I = PAT"- model type, describes environmental (I)mpact against the (P)opulation, (A)ffluence and (T)echnology. Technology covers energy use per unit of GDP as well as carbon emissions per unit of energy consumed (Kaya \& Yokoburi, 1997).

In theories of climate change, the focus is upon so-called anthropogenic causes of global warming through the release of Greenhouse Gases (GHG). To halt the growth of the GHG:s, of which CO2:s make up about 70 per cent, one must theorize the increase in $\mathrm{CO} 2$ :s over time (longitudinally) and its variation among countries (cross-sectionally). As a matter of fact, $\mathrm{CO} 2$ :s have very strong mundane conditions in human needs and social system prerequisites. Besides the breading of living species, like 
Homo sapiens for instance, energy consumption plays a major role. As energy is the capacity to do work, it is absolutely vital for the economy in a wide sense, covering both the official and the unofficial sides of the economic system of a country. The best model of carbon emissions to this day is the so-called Kaya model.

It may seem premature to speak of a Kaya's law or identity that explains carbon emissions completely, as if the so-called Kaya identity is a deterministic natural law. It will not explain all the variation, as there is bound to be other factors that impact, at least to some extent. Thus, it is more proper to formulate it as a stochastic law-like proposition, where coefficients will be estimate using various data sets, without any assumption about stable universal parameters. Thus, we have this equation format for the Kaya probabilistic law-like proposition, as follows:

(E1) Multiple Regression: $Y=a+b_{1} X_{1}{ }^{+} b_{2} X_{2}+b_{3} X_{3}+\ldots+b_{t} X_{t}+u$

Note: $\mathrm{Y}=$ the variable that you are trying to predict (dependent variable); $\mathrm{X}=$ the variable that you are using to predict $\mathrm{Y}$ (independent variable); $\mathrm{a}=$ the intercept $\mathrm{b}=$ the slope; $\mathrm{u}=$ the regression residual. Note: http://www.investopedia.com/terms/r/regression.asp\#ixzz4Mg4Eyugw

Thus, using the Kaya model for empirical research on global warming, the following anthropogenic conditions would affect positively carbon emissions:

(E2) CO2:s = F (GDP/capita, Population, Energy intensity, Carbon intensity), in a stochastic form with a residual variance, all to be estimated on data from some 59 countries. I make an empirical estimation of this probabilistic Kaya model-the cross-sectional test for 2014:

(E3) $\mathrm{k} 1=0,68, \mathrm{k} 2=0,85, \mathrm{k} 3=0,95, \mathrm{k} 4=0,25 ; \mathrm{R} 2=0.90$.

Note: $\mathrm{LN} \mathrm{CO} 2=\mathrm{k} 1 * \mathrm{LN}(\mathrm{GDP} /$ Capita $)+\mathrm{k} 2 *($ dummy for Energy Intensity $)+\mathrm{k} 3 *$ (LN Population $)+$ k4* (dummy for Fossil Fuels/all) Dummy for fossils 1 if more than $80 \%$ fossil fuels; $\mathrm{k} 4$ not significantly proven to be non-zero, all others are $(\mathrm{N}=59)$.

\section{Framework of Analysis}

We need to model this energy-emission dilemma for the countries of the COP21 project. To understand the predicament of Third World countries, we need to know whether GHC:s or CO2:s are still increasing (Goal I) and what the basic structure of the energy mix is (Goal II). Thus, I suggest:

$<$ GDP-GHG (CO2) link, energy mix >, as a model of the decarbonisation feasibility in some Third World countries, to be analysed below, following the so-called "Kaya" model. The first concept taps the feasibility of Goal I: halting the growth of GHG:s or CO2:s, whereas the other concepts target the role of fossil fuels and wood coal like charcoal.

The difference between global warming concern and general environmentalism appears clearly in the evaluation of atomic power. For reducing climate change, nuclear power is vital, but for environmentalism atomic power remains a threat. From a short-term perspective, the global warming concerns should trump the fear of radioactive dissemination, as global warming will hit mankind much sooner. In the Third World, nuclear power plants are increasing in number, whereas in the mature 
economies their number is being reduced. New nuclear technology is much safer, why also advanced countries should use this option, like now for instance the UK.

The most recent information about global $\mathrm{CO}$ :s indicate that the typical upward sloping curve has stalled but not declines. A few countries display downward sloping curves: the Nordic countries, several EU countries, the US, Japan and Australia. But several other countries have an upward sloping curve, here analysed as the link between GDP and GHG:s or CO2:s.

It cannot be enough emphasized that each country government is in effect the decisive player in this global game, because the approach to decarburization is a decentralized one. Global governance has promised to help and assist financially, but it is just a promise about a phenomenal Super Fund. The country analyses below follow the implementation of the two goals in the COP21 project:

- Halting the upward sloping GDP-CO2 curve-GOAL I;

- Transforming the energy mix away from wood coal and fossil fuels-GOAL II.

\section{The Tragedy of South Asia}

Just because there is an agreement it does not entail it will be respected. Even if respecting the promises made is the best strategy for all partners to the dal, each individual has an incentive to renege upon the agreement. In two-person game theory, a few much discussed models portray coordination failures, and they are applicable to governments as well as international governance. If, as shown above with the Kaya model, decarbonisation may be costly, hurting economic development, then perhaps a country may simply go its own way, leaving it up to the other(s) to handle the externalities in global warming. Why make costly contributions to collective action? Remember that small countries do not matter much (N-1 problematic) and huge countries would have to share the benefits with all others (I/N problematic).

The interaction between nations and their governments can be of two kinds: zero sum game or variable sum game. Halting the climate change process constitutes a Pareto optimal goal for all participants with means of collective action, coordination either by themselves or with a third party, an international governance body like that of the UNFCCC. However, coordination may fail to reach a set of Pareto optimal outcomes, as the choice participants

I will analyse a few important countries in a comparative fashion so that they can be compared systematically. Two diagrams will be presented for each country, related to the research approach above. First, the COP21 Goal I will be tapped by looking at the curve between GDP and CO2:s (GHG:s), whether is rising or declining and whether it slopes outward or inward. Second, the COP21 Goal II is enquired into, as the energy consumption mix is portrayed: the more reliance upon fossil fuels and charcoal, the more costly the energy transition. What matters in both diagrams are both absolute and relative numbers. Thus, the coal share of energy resources may go down, but if total energy consumed is up, emissions will remain at a high level.

A set of countries with huge population at a low level income per person will find the COP21 
objectives too exigent. They have to plan for more of energy in order to strengthen economic development against widespread poverty amidst string population growth. These countries can only promote Goal I and Goal II, if supported by the Super Fund.

India

India will certainly appeal to the same problematic, namely per capita or aggregate emissions. The country is more negative than China to cut GHG emissions, as it is in an earlier stage of industrialization and urbanization. Figure 1 shows the close connection between carbon emissions and GDP for this giant nation.

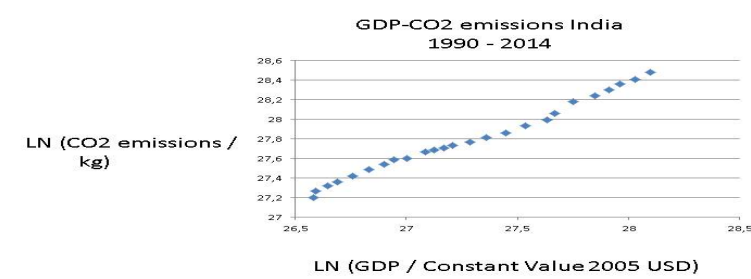

Figure 1. India: Link between GDP and CO2: $y=0,77 x+6,79 ; R^{2}=0,99$

India needs cheap energy for its industries, transportation and heating as well as electrification. From where will it come? India has water power and nuclear energy, but relies most upon coal, oil and gas as power source. It has strong ambitions for the future expansion of energy, but how is it to be generated, the world asks. India actually has one of the smallest numbers for energy per capita, although it produces much energy totally. Figure 2 shows its energy mix where renewables play a bigger role than in for instance China.

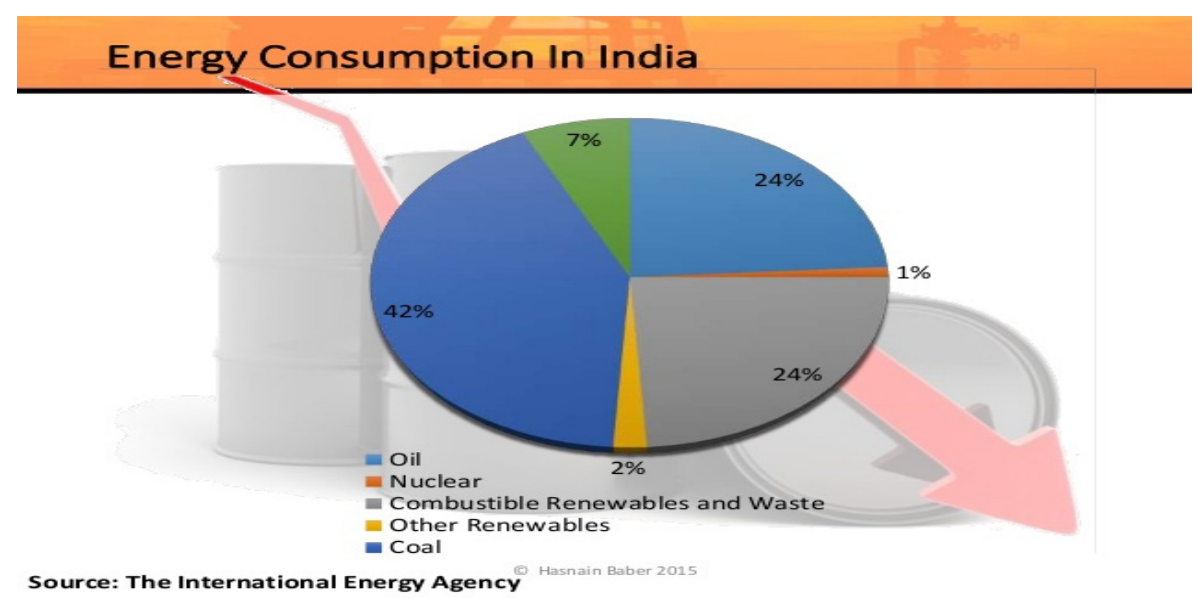

Figure 2. India's Energy Mix 
India needs especially electricity, as 300 million inhabitants lack access to it. The country is heavily dependent upon fossil fuels (70 per cent), although to a less extent than China. Electricity can be generated by hydro power and nuclear power, both of which India employs. Yet, global warming reduces the capacity of hydro power and nuclear power meets with political resistance. Interestingly, India uses much biomass and waste for electricity production, which does not always reduce GHG emissions. India's energy policy will be closely watched by other governments and NGO:s after 2018. Wood coal is conducive to deforestation and desertification.

\section{Pakistan}

The same upward trend for emissions holds for another major developing country with huge population, namely Pakistan (Figure 3).

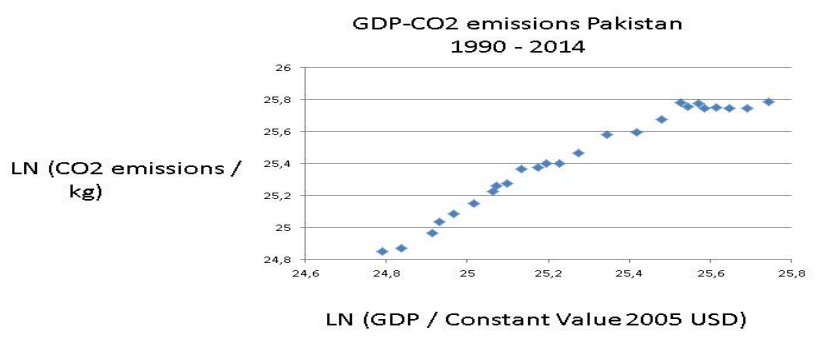

Figure 3. Pakistan: GDP-CO2: $y=1,05 x-0,97 ; R^{2}=0,96$

The amount of GHG emissions is rather large for Pakistan, viewed on aggregate. Pakistan is mainly reliant upon fossil fuels (Figure 4).

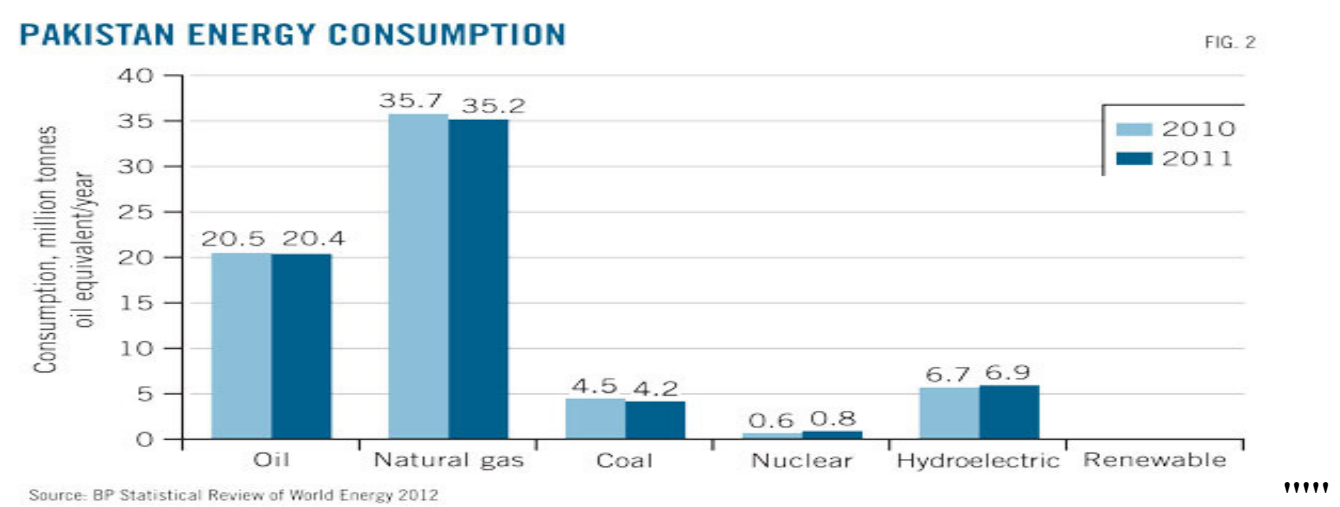

Figure 4. Energy Consumption in Pakistan 
But Pakistan employs a considerable portion of hydropower-13 per cent — and a minor portion of nuclear power, which is a positive.

\section{Bangladesh}

Moving on to another giant nation in South Asia, Bangladesh, we find an entirely different set of conditions for implementing COP21. Figure 6 shows that the major GHC of $\mathrm{CO} 2$ :s follows economic development closely.

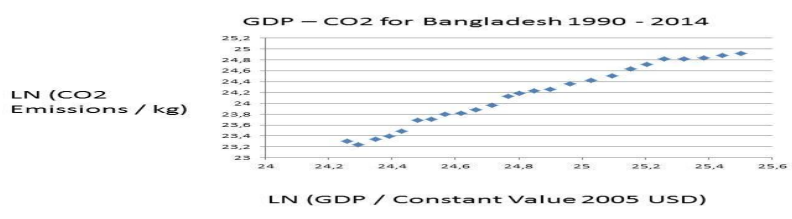

Figure 5. Bangladesh's GDP-CO2 Link $\left(y=1,43 x ; R^{2}=0,98\right)$

Yet energy consumption is based on a different energy mix, compared with for instance India. Figure 6 pins down the large role of traditional renewables like wood, charcoal and dung as well as the heavy contribution of oil and gas. Bangladesh needs external support for developing modern renewables, like solar, wind and geo-thermal power sources.

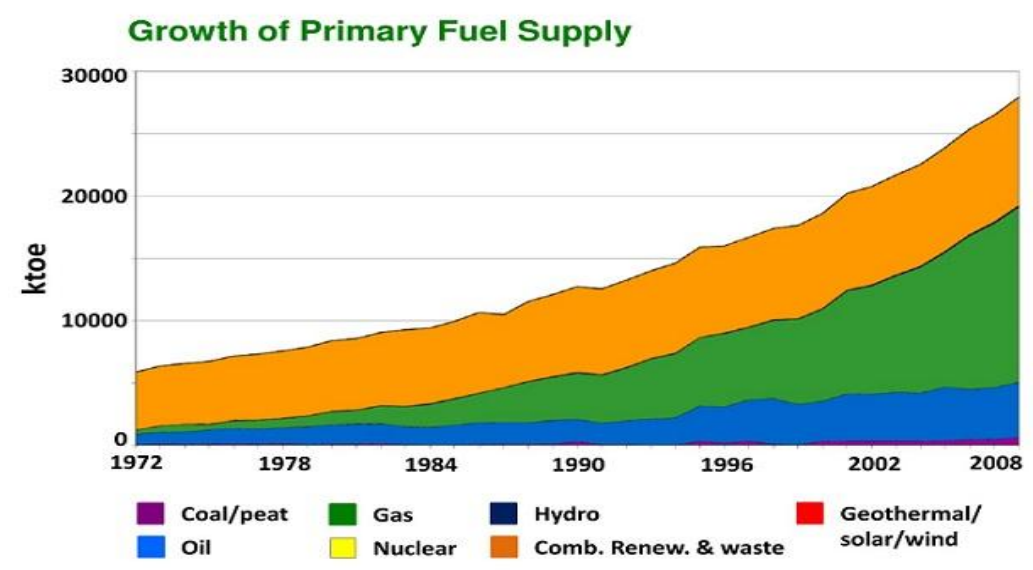

Figure 6. Energy Mix in Bangladesh

Source: Energy Scenario in Bangladesh from 1972-2008 (Orange: Biomass, Green: Gas, Blue: Oil).

\section{Sri Lanka}

When examining small but populous Sri Lanka, one sees again the strong connection between GDP and $\mathrm{CO} 2$ :s - see Figure 7. It seems that the $\mathrm{CO} 2$ :s was halted in their expansion for some time, but now they increase again. 


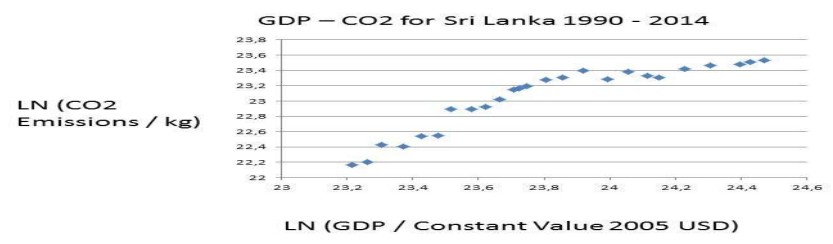

Figure 7. Sri Lanka: GDP-CO2 $\left(y=1,03 x ; R^{2}=0,84\right)$

In this island state, the dominant energy source is traditional renewables, which leads to deforestation and $\mathrm{CO} 2$ emissions on a large scale (Figure 8). It has been argued that the forest will grow up again, eating the carbon emissions. But it is mainly wishful thinking, as climate change and draughts make forest rehabilitation difficult.

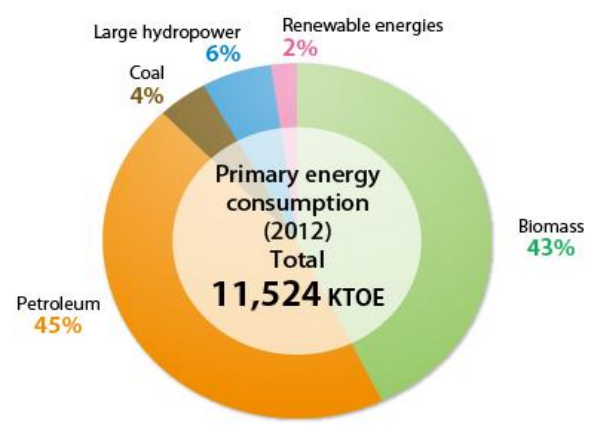

Figure 8. Sri Lanka's Energy Consumption

Source: Primary energy consumption in Sri Lanka (2012);

http://www.info.energy.gov.lk/

For the poor nations in Asia with huge population holds that they cannot by themselves accomplish the objectives of COP21: Goal I: reverse current $\mathrm{CO} 2$ trend, Goal II: reduce by 40 per cent the $\mathrm{CO} 2$ :s by 2030 and Goal III: full decarbonisation by 2075. As a matter of fact, they will need massive financial assistance from the Super Fund, which has still not been founded.

Yet, this requires that the COP21 or CO22 sets up a management structure to assist these countries involving project evaluation, policy execution and implementation, control of financial flows and outcome assessment — a gigantic task with many pitfalls involved.

\section{Catch-up Countries}

We examine a few more examples from Asia—l'usine du monde, like, e.g., Thailand and Malaysia. They follow the catch-up strategy at almost any cost to the environment. 
A medium income country with a not too large population can innovate, thus promoting decarbonisation by itself. But it may accomplish a more radical change with support from the Super fund, which entails extensive bargaining between the country and international governance bodies. Is a Pareto optimal outcome achievable, making Goal I and Goal II realities as outcomes?

\section{Thailand}

Figure 9 begins with Thailand that has become a rapidly developing country with increasing affluence and is besides furnishing large scale tourism a major car producer inter alia.

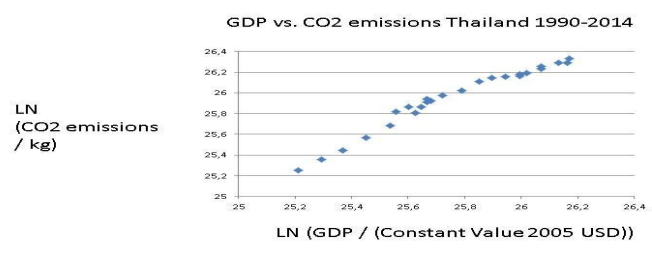

Figure 9. Thailand's Link $\left(y=1,07 x ; R^{2}=0,96\right)$

The $\mathrm{CO} 2$ emissions in Thailand are quite high, reflecting the economic advances in South East Asia. The trend is up and up. Can it be reversed without serious economic impact? Figure 10 shows the energy mix of this dynamic country, economically.

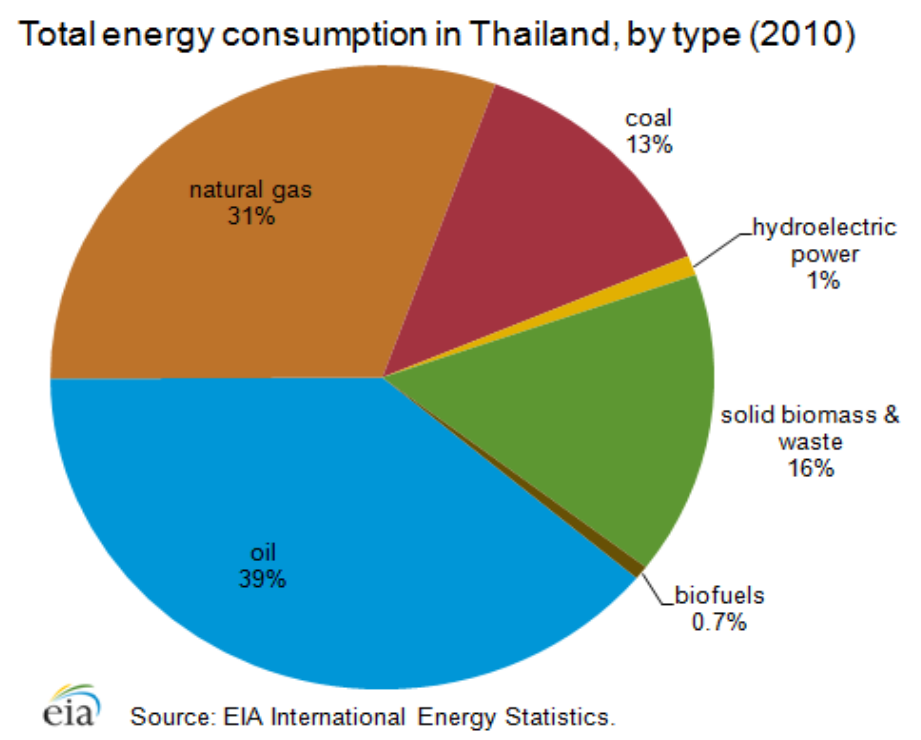

Figure 10. Energy Mix for Thailand

The reliance upon fossil fuels is high, or over $80 \%$ of energy consumption coming from the burning of coal, oil and natural gas. Hydro power is marginal, but bio-energy plays a major role, but it is really not 
carbon neutral. Thailand needs to come up with far-reaching reforms of its energy sector in order to comply with COP21 objectives.

\section{Malaysia}

The overall situation — fossil fuels dependency—is the same for Malaysia as for Thailand. And the $\mathrm{CO}$ :s are high, following the GDP trend (Figure 11).

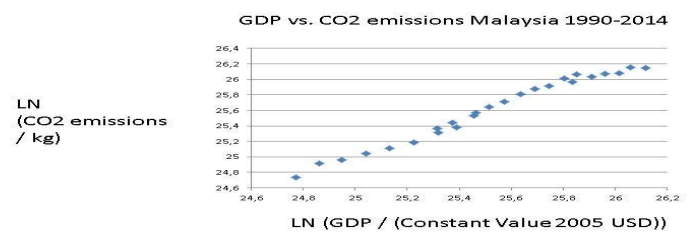

Figure 11. Malaysia $\left(y=1,13 x ; R^{2}=0,98\right)$

Yet, Malaysia employs energy of a very mixed bag (Figure 12), but still its emissions augment in line with economic development. There may be a planning out of the growth trend in emissions recently, but Malaysia use very little of carbon neutral energy sources. There is hydro power, but the country must move to solar and wind power rapidly.

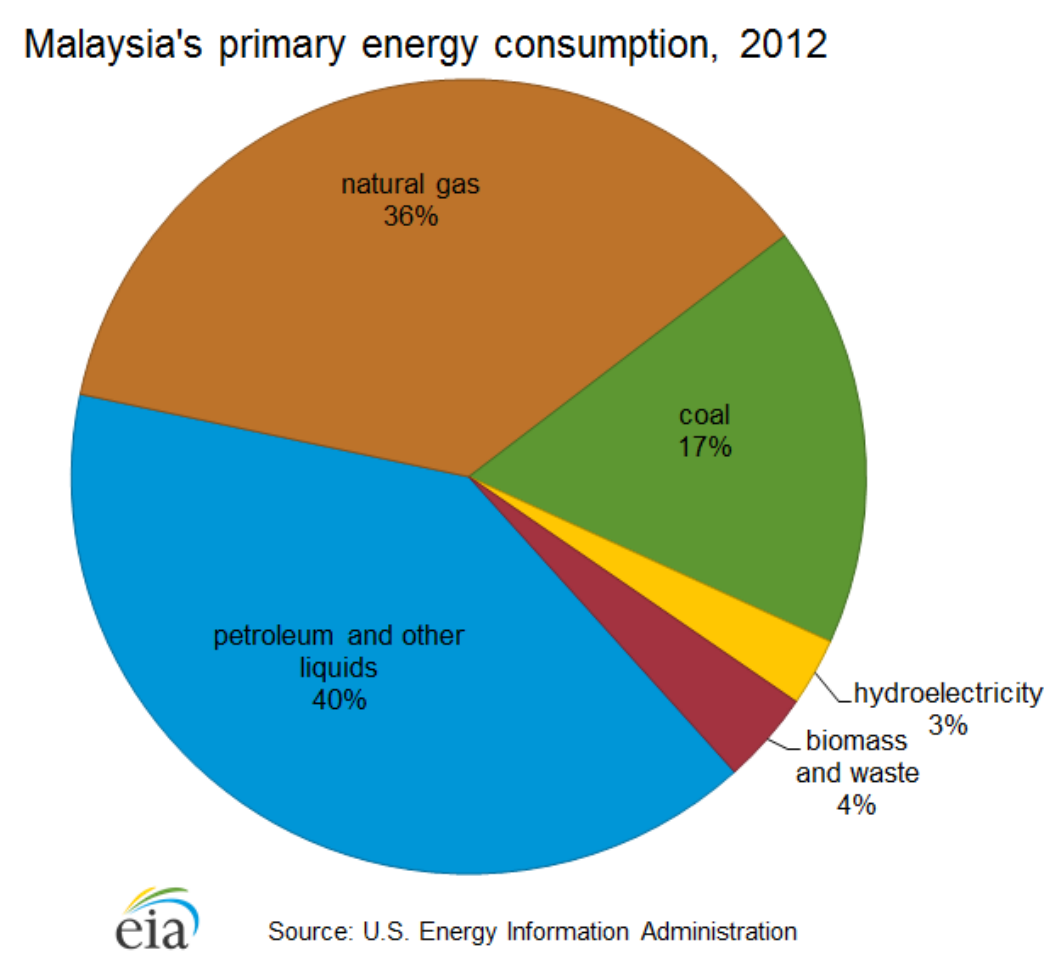

Figure 12. Energy Consumption in Malaysia 
Renewables are not a major element in the energy consumption mix of Malaysia, as fossil fuels dominate, but not coal luckily.

\section{Take-off Nations}

The Asian miracle economically moves from one nation to another, Now a few big countries have started quich economic development - the "take-off" stage.

\section{Indonesia}

One may guess correctly that countries that try hard to "catch-up" will have increasing emissions. This was true of India. Let us look at three more examples, like, e.g., giant Indonesia-now the fourth largest emitter of GHG:s in the world (Figure 13).

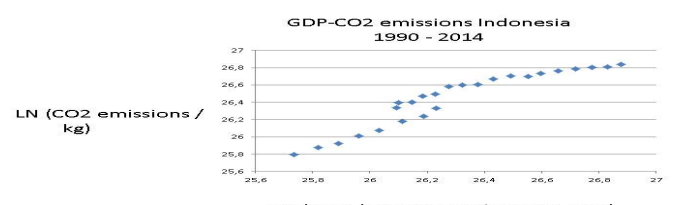

LN (GDP / Constant Value zoos USD)

Figure 13. Indonesia: GDP-CO2 Link $\left(y=0,95 x+1,58 ; R^{2}=0,89\right)$

Indonesia is a coming giant, both economically and sadly in terms of pollution. Figure 13 reminds of the upward trend for China and India. However, matters are even worse for Indonesia, as the burning of the rain forest on Kalimantan and Sumatra augments the GHG emissions very much. Figure 14 presents the energy mix for this huge country in terms of population and territory.

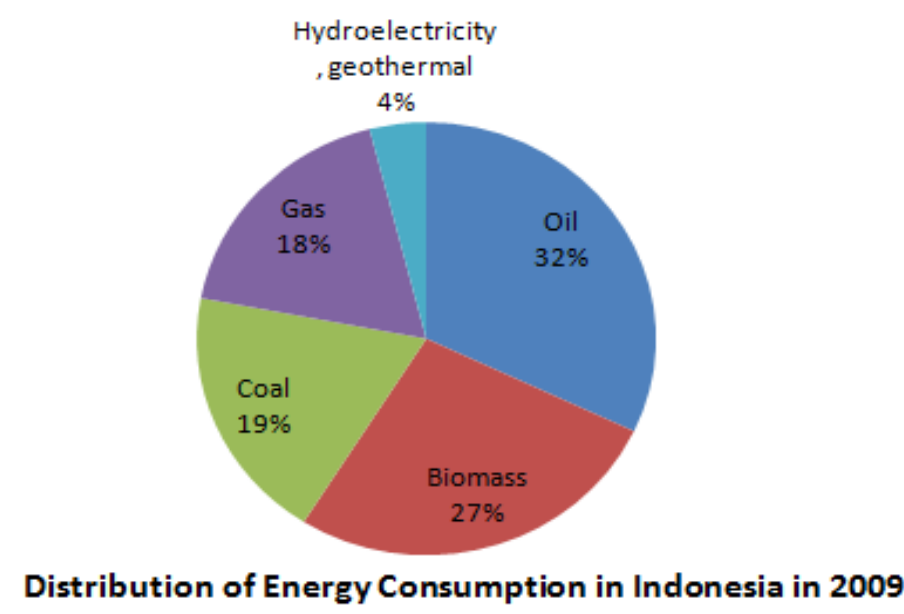

Figure 14. Indonesian Energy

http://www.missrifka.com/energy-issue/recent-energy-status-in-indonesia.html

Published by SCHOLINK INC. 
Only 4 per cent comes from hydro power with 70 per cent from fossil fuels and the remaining 27 per cent from biomass, which alas also pollutes.

\section{Vietnam}

To further substantiate the argument about the $\mathrm{CO} 2$-energy conundrum that countries all over the world face, we may look at two populous nations in Asia with quickly expanding economies: Vietnam and the Philippines. They have both upward sloping trends for emissions, energy consumption and GDP, as the Kaya model entails.

Vietnam is now the perhaps most dynamic economy in Asia, after years of socialism and a planned economy. Such fast economic growth requires one thing especially, namely energy (Figure 15).
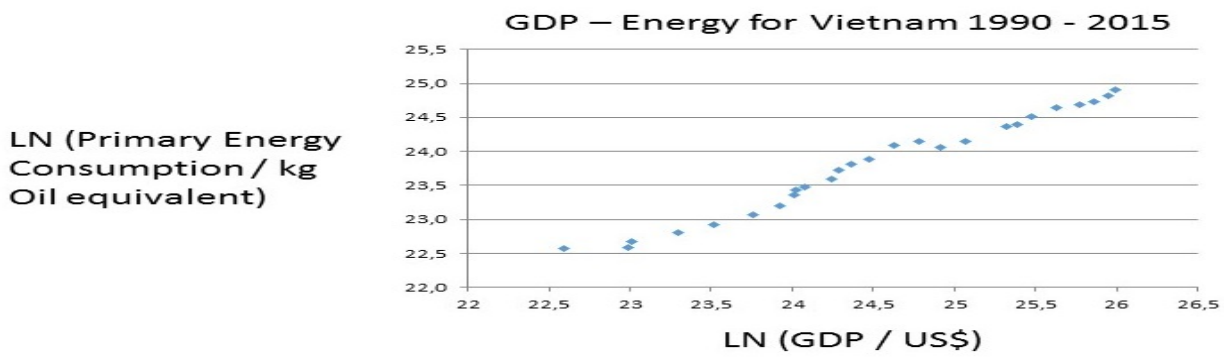

Figure 15. Vietnam: GDP and Energy $\left(y=0,74 x ; R^{2}=0,98\right)$

The benefits of such a strong economic development is of course raising affluence and diminishing poverty. But the costs involve much more emissions (Figure 16).

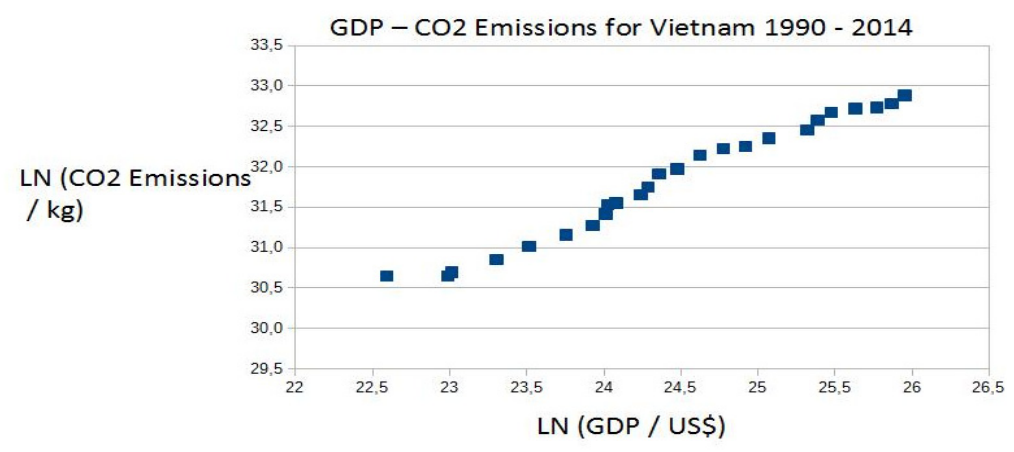

Figure 16. GDP and Emissions for Vietnam $(y=0.75 x+13,4 ; R 2=0,9)$

How Vietnam is to change in order to promote the COP21 goals, Goal I and Goal II) within a short period of some 10 years, given the ambition to maintain raid economic growth, is very difficult to understand. Can really renewables do the trick? It is a highly relevant policy question, despite the massive employment of hydro power in this country.

\section{The Philippines}


Giant nation the Philippines is very interesting, as they claim that they can handle the implementation of the COP21 goals. This may simply be rhetoric, which is just another form of reneging upon promises. Consider first the upward sloping trend in Figure 17.

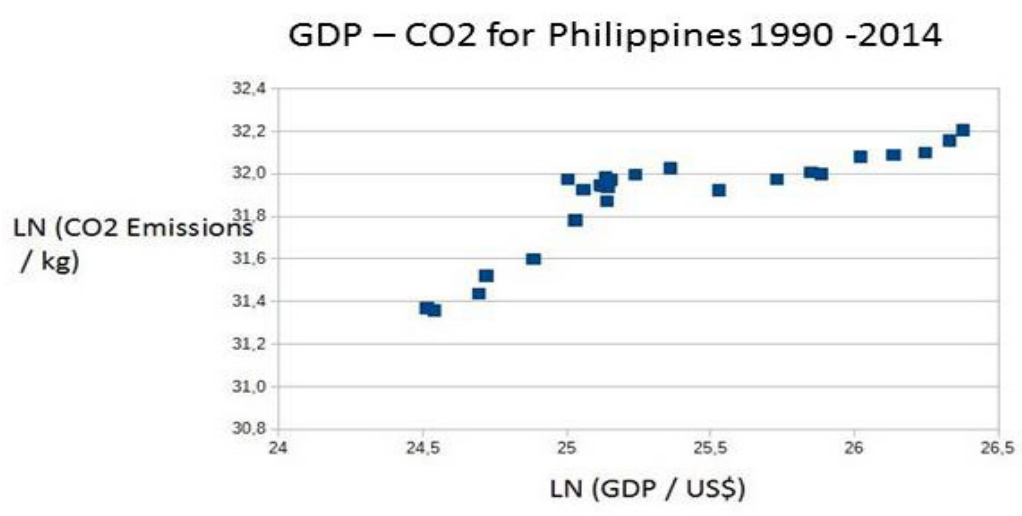

Figure 17. The Philippines: $y=0,36 x+23 ; R 2=0,68$

No wonder that this Figure 17 has a strong upward trend for emissions when one examines its pattern $\mathrm{f}$ energy consumption (Figure 18).

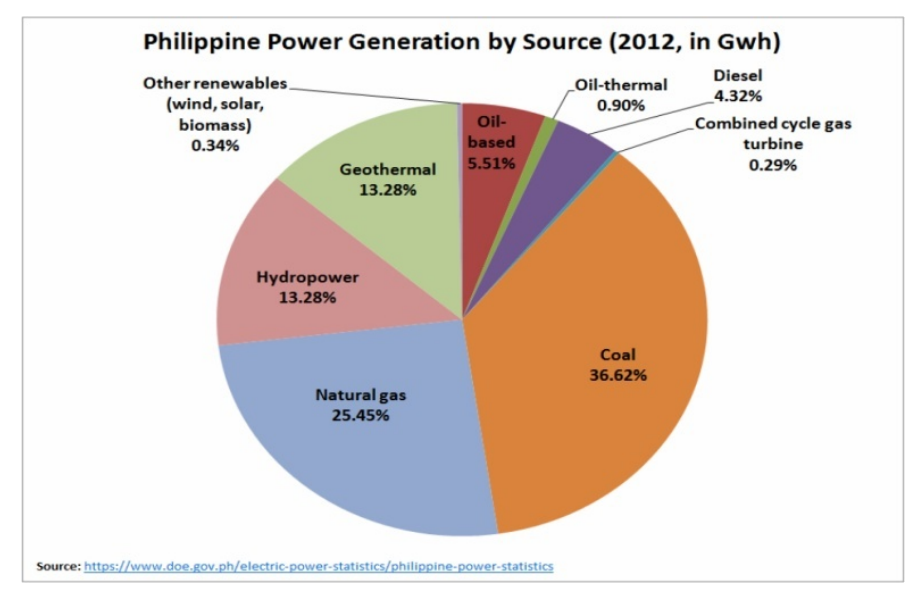

Figure 18. Energy Mix in the Philippines

The energy profile of the Philippines is actually more positive than several of the countries above, including a huge part of geo-thermal energy. Yet, fossil fuels dominate to a high 70 per cent, as in other populous and rapidly developing nations. The Philippines definitely needs help from the Super Fund.

The caching-up countries all have increasing slopes for the GDP-CO2 link, which entails profound difficulties to come for the accomplishment of Goal $\mathrm{I}$ in the $\mathrm{CO} 21$ project. In relation to the achievement of Goal II, one can say only note that tremendous investments have to be made by these countries in renewable energy and atomic plants, which they will find difficult to do. 


\section{East Asia: Ferocious Global Competitors in Need of Energy}

A few nations do not depend upon any foreign assistance, because they are highly developed technologically and can draw upon own substantial financial resources. One may find that the emissions of GHG:s follows economic development closely in many countries. The basic explanation is population growth and GDP growth-more people and higher life style demands. Take the case of China, whose $\mathrm{CO} 2$ emissions are the largest in the world, totally speaking (Figure 19). China was a Third World country up until yesterday.

China

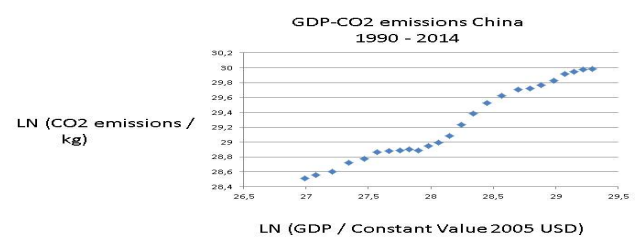

Figure 19. China: GDP-CO2 Link: $y=0,70 x ; R^{2}=0,97$

The sharp increase in $\mathrm{CO} 2 \mathrm{~s}$ in China reflects not only the immensely rapid industrialization and urbanization of the last 30 years, but also its problematic energy mix (Figure 20).

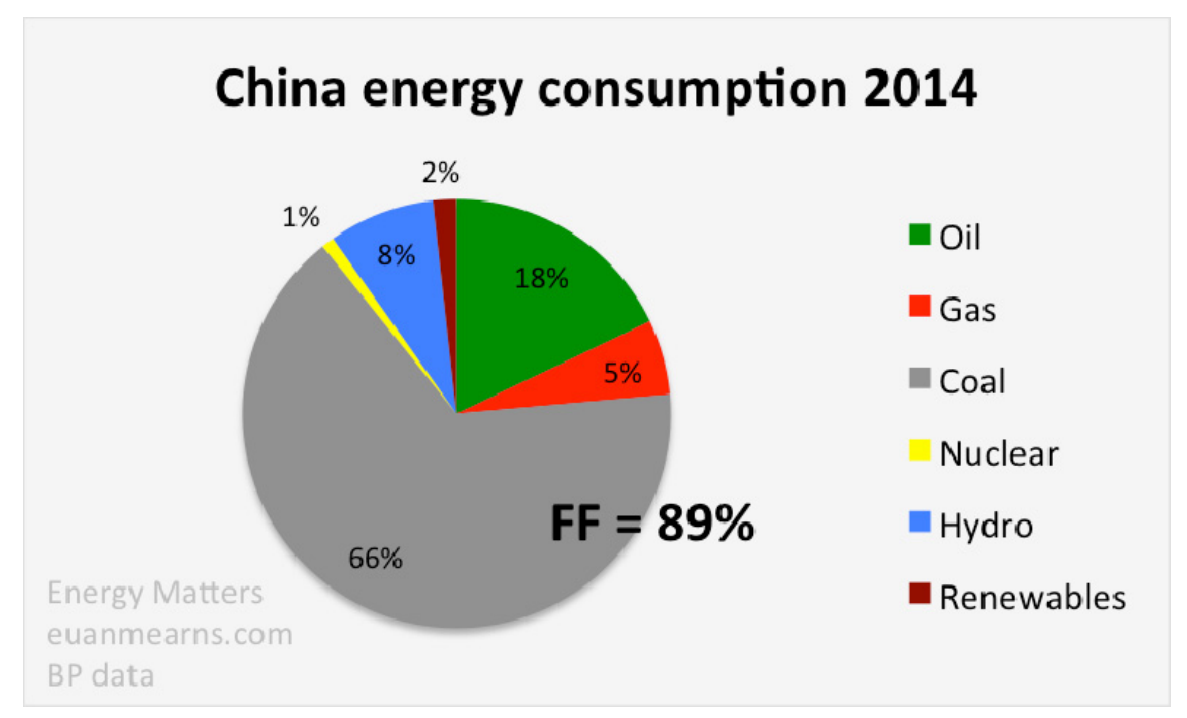

Figure 20. China's Energy Mix

Almost 70 per cent of the energy consumption comes from the burning of coal with an additional 20 per cent from other fossil fuels. The role of nuclear, hydro and other renewable energy sources is small Published by SCHOLINK INC. 
indeed, despite new investments. This makes China very vulnerable to demands for cutting GHG emissions: other energy sources or massive installation of highly improved filters?

It should be pointed out that several small countries have much higher emissions per capita than China. This raises the enormously difficult problematic of fair cuts of emissions. Should the largest polluters per capita cut most or the biggest aggregate polluters? At COP21 this issue was resolved by the creation of a Super Fund to assist energy transition and environment protection in developing counties, as proposed by economist Stern (2007). But China can hardly ask for this form of foreign assistance. It is true that China energy consumption is changing with much more of renewables ad atomic plants. But so is also demand increasing with new and bigger cars all the time plus increased air traffic on huge new airports. Can China really cut $\mathrm{CO} 2$ :s with 40 per cent while supply almost 50 per cent more energy power, according to plan?

\section{South Korea}

Industrial giant South Korea is very interesting from the perspective of the COP21 Agreement, because the basic trend violates both Goal I and Goal II. An entirely different trend than that of other mature economies is to be found in South Korea (Figure 26), which has "caught up" in a stunning speed but with enormous GHG emissions.

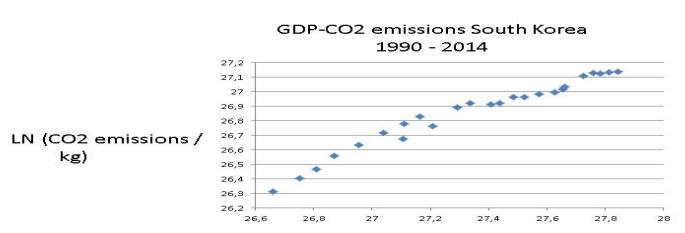

LN (GDP / Constant Value 2005 USD)

Figure 21. South Korea's Link GDP - CO2: $y=0,65 x+9,19 ; R^{2}=0,96$

Lacking much hydro power, South Korea has turned to fossil fuels for energy purposes, almost up to 90 per cent (Figure 22). Now, it builds nuclear plants, but South Korea needs to move aggressively into solar power to reverse trends. 


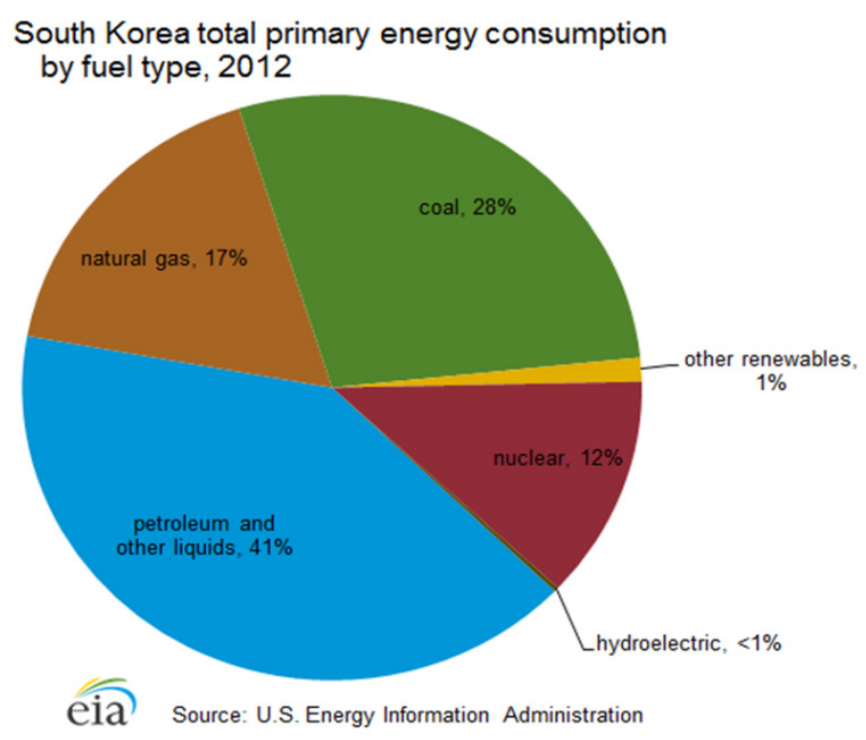

Figure 22. Energy in South Korea

It differs from China only in the reliance upon nuclear power, where the country is a world leader in plant constructions. Reducing its GHG emissions, South Korea will have to rely much more upon renewable energy sources, as well as reducing coal and oil for imported gas or LNGs. China or South Korea are on line for fulfilling the COP21 Goal I, as they are not reducing their emissions, like other advanced or mature economies as Japan, the EU and some EU nations. Goal II seems far away in terms of achievement for these two industrial giant, still very dependent upon fossil fuels. They innovate with renewables, but hope to consume even more energy in the coming decade.

\section{Japan}

Japan started the Asian growth miracle, although without internal energy resources. As the economy of Japan stagnated in the 1990s and the country began using nuclear power massively, Japan managed a dramatic reduction in the emission of greenhouse gases in the first decade of the new century.

$\mathrm{LN}\left(\mathrm{GHG} / \mathrm{Kg} \mathrm{CO}_{2}\right.$ eq. $)$

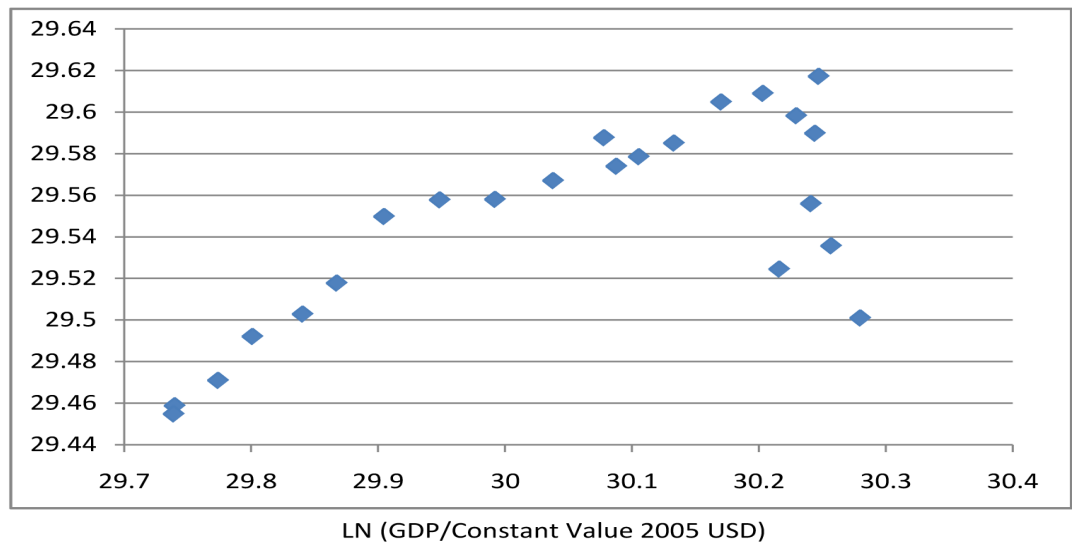

Figure 23. Japan's GDP-CO2 Link: $y=0.2648 x ; \mathrm{R}^{2}=0.194$ 
However, the numbers will go up again to high levels of emissions. It is hardly a daring guess that the nuclear plant disaster in Japan together with the decision to close most such power plants has further increased emissions, as the country now relies upon fossil fuels much more. Governments make plans, but they may not hold for unforeseen developments. Take the case of Japan (Figure 24).

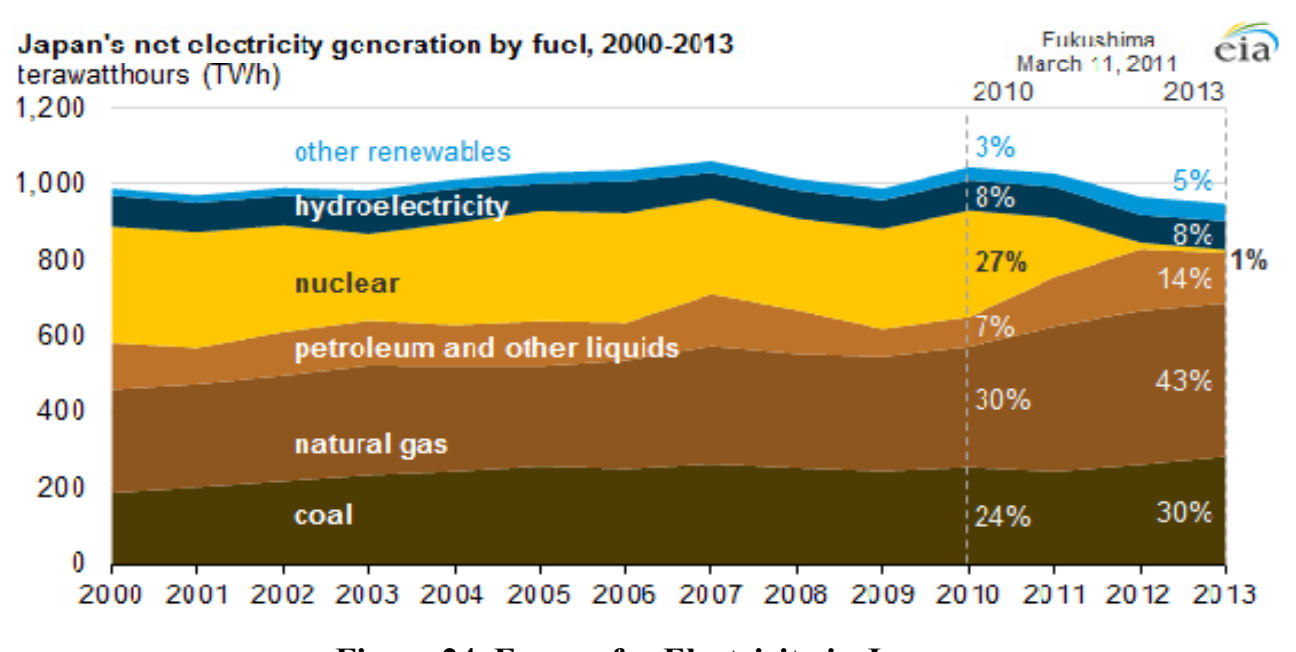

Figure 24. Energy for Electricity in Japan

Japan is today more dependent upon fossil fuels than earlier due to the debacle with its nuclear energy program. Is really solar, wind or atomic power realistic in Japan on the scale needed for massive decarbonisatin? When forced, governments renege, i.e. they will turn back to the fossil fuels, as for them economic growth trumps the environment. After all, nations are brutally egoistic, at least according to standard teachings in international relations.

\section{Conclusion}

The Asian economic miracle has since 1950 spread out in concentric circles from Japan. Now the whole of the far Asian region is included plus South Asia, making up the most dynamic part of the global market economy. A chief element in this phenomenal economic expansion, undoing all talk about Western or Protestant economic superiority—Max Weber (SwatosJr \& Kaelber, 2005)— has been the employment of cheap energy. Energy is the capacity to do work. And work is the foundation of affluence. But the risk is overwhelming that Asia will overheat due to the energy-emissions conundrum. Asians will have to live like Singaporeans, in eternal air-conditioning. But air-conditioning fuels climate change- the perfect circulus vitiosus.

The plans with the major Asian players — governments, think tanks, oil producing firms, banks — are for much more energy consumption the coming decades - contradicting decarbonisation. Public intellectual Ramesh (2015) admits that India cannot do without coal, wood or stone coal. Modern capitalism in Asia has been enormously successful driven by the acquisitive spirit a la Tawney (2016), but it can no longer rely upon the fruits of the miracles. 


\section{References}

\section{GDP sources:}

World Bank national accounts data. (n.d.). Retrieved from http://www. data.worldbank.org

OECD National Accounts data files. (n.d.).

\section{GHG and energy sources:}

World Resources Institute CAIT Climate Data Explorer. (n.d.). Retrieved from http://www.cait.wri.org EU Joint Research Centre Emission Database for Global Atmospheric. (n.d.).

Research. (n.d.). Retrieved from http://www.edgar.jrc.ec.europa.eu/overview.php

UN Framework Convention on Climate Change. (n.d.).

http://www.unfccc.int/ghg_data/ghg_data_unfccc/time_series_annex_i/items/3814.php

International Energy Agency. (n.d.). Paris.

Energy Information Administration. (n.d.). Washington, DC.

BP Energy Outlook 2016. (n.d.).

EU Emissions Database for Global Research EDGAR. (n.d.).

http://www.edgar.jrc.ec.europa.eu/

World Bank Data Indicators. (n.d.). Retrieved from http://www.data.worldbank.org

British Petroleum Statistical Review of World Energy 2016Literature. (n.d.).

\section{Literature B}

Barry, B. (1982). The Tradition of Spontaneous Order. Literature of Liberty (Vol. v, No. 2, pp. 7-58). Arlington, VA: Institute for Humane Studies.

Hayek, F. A. (1991). The Fatal Conceit: The Errors of Socialism. The University of Chicago Press.

Kaya, Y., \& Yokoburi, K. (1997). Environment, energy, and economy: Strategies for sustainability. Tokyo: United Nations University Press.

Sachs, J. (August 10th, 2015). Sustainable Development for Humanity's Future. Retrieved from http://www.jeffsachs.org/2015/08/sustainable-development-for-humanitys-future/

Sachs, J. D. (2015). The Age of Sustainable Development. New York: Columbia University Press. https://doi.org/10.7312/sach17314

Stern, N. (2007). The Economics of Climate Change. Oxford: OUP. https://doi.org/10.1017/CBO9780511817434

Swatos Jr, W. H., \& Kaelber, L. (2005). The Protestant Ethic Turns 100: Essays on the Centenary of the Weber Thesis. London: Routledge,

Ramesh, J. (2015). Green Signals: Ecology, Growth and Democracy in India (2015). Oxford : Oxford University Press. https://doi.org/10.1093/acprof:oso/9780199457526.001.0001

Tawney, R. (1922). The Acquisitive Society. Leopold Classic Library, 2016. 